\title{
Standard culture of Paratanytarsus grimmii Schneider, 1885 (Diptera: Chironomidae), for its use in toxicity bioassays.
}

\author{
F. Encina ${ }^{a, b *}$ (D), P. De los Ríos ${ }^{b, c}$ (D), R. Vegad,e (D) and A. Mardones ${ }^{d, e}$ (1) \\ aDepartamento de Ciencias Ambientales, Facultad de Recursos Naturales, Universidad Católica de Temuco, \\ Casilla 15-D, Temuco, Chile \\ bNúcleo de Estudios Ambientales, Universidad Católica de Temuco, Casilla 15-D, Temuco, Chile \\ 'Departamento de Ciencias Biológicas y Químicas, Facultad de Recursos Naturales, Universidad Católica de Temuco, \\ Casilla 15-D, Temuco, Chile \\ dDepartamento de Ciencias Agropecuarias y Acuicolas, Facultad de Recursos Naturales, Universidad Católica de Temuco, \\ Casilla 15-D, Temuco, Chile \\ eNúcleo de Producción Alimentaria, Universidad Católica de Temuco, Casilla 15-D, Temuco, Chile \\ *e-mail: fencina@uct.cl
}

Received: January 17, 2019 - Accepted: July 18, 2019 - Distributed: November 30, 2020

(With 2 figures)

\begin{abstract}
The management and use of native species under laboratory conditions is the main difficult for species proposal for its use in bioassays. The present study showed the results about management under controlled conditions of Paratanytarsus grimmii (Diptera: Chironomidae), that is a parthenogenetic species with wide geographical distribution. It obtained its eggs from a pre Andean river from Araucania region $\left(39^{\circ} \mathrm{S}\right)$, and it determined the conditions for larval rearing under artificial food, adults getting (manipulation), eggs (hatching sincronization) and larvae getting after hatching. The P.grimmii life cycle had larvae that late 23 days in get the pupa stage (stage I to IV), the adult within the next 48 hours deposits the eggs that hatched at 72 hours. It stablished laboratory conditions: incubation room temperature, water $\mathrm{pH}$, and artificial feeding, photoperiod and larvae and eggs management techniques. In according to obtained results it managed all life cycles under laboratory conditions that can propose the use of this species as potential biological material for toxicity bioassays.
\end{abstract}

Keywords: Paratanytarsus grimmii, chironomidae, life cycle, bioassays.

\section{Cultura padrão de Paratanytarsus grimmii Schneider, 1885 (Diptera: Chironomidae), para uso em bioensaios de toxicidade}

\section{Resumo}

O manejo e o uso de espécies nativas em condições de laboratório são as principais dificuldades para a proposta de uso de espécies em bioensaios. O presente estudo mostrou os resultados acerca do manejo sob condições controladas de Paratanytarsus grimmii (Diptera: Chironomidae), espécie partenogenética com ampla distribuição geográfica. Foram obtidos seus ovos de um rio pré-andino da região de Araucanía ( $\left.39^{\circ} \mathrm{S}\right)$ e determinadas as condições para criação de larvas sob alimentação artificial, obtenção de adultos (manipulação), de ovos (sincronização de eclosão) e de larvas após a eclosão. O ciclo de vida de $P$. grimmii teve larvas que, ao final dos 23 dias, atingiram o estágio de pupa (estágio I a IV). O adulto depositou nas 48 horas seguintes os ovos que eclodiram às 72 horas. Foram estabelecidas condições laboratoriais: temperatura da sala de incubação, $\mathrm{pH}$ da água e alimentação artificial, fotoperíodo e técnicas de manejo de larvas e ovos. De acordo com os resultados obtidos, foram gerenciados todos os ciclos de vida em condições de laboratório que podem propor o uso dessa espécie como material biológico potencial para bioensaios de toxicidade.

Palavras-chave: Paratanytarsus grimmii, chironomidae, ciclo de vida, bioensaios.

\section{Introduction}

The protection conditions for inland water ecosystems, mainly for northern Chilean Patagonia $\left(38-40^{\circ} \mathrm{S}\right)$, requires an integral or ecosystem approach due the origin and evolution of these ecosystems, that have low human intervention, low species diversity, high endemism and primitivity of the species (De los Ríos-Escalante et al., 2013). It is necessary to know the ecotoxicological response of native species that coexist in environments exposed to xenobiotic substances incorporated to the ecosystems due anthropogenic activity (Encina et al., 2017a, b). 
Currently, the inland water protection ecosystems in Chile is done by the control of chemical conditions under Environmental Impact Evaluation System (SEIA), that regulate the minimum and maximum values of determined level for concentration substances, energy isolated or combined. But there are not a causal relation between these elements and the effects of local environments (Encina et al., $2017 \mathrm{a}, \mathrm{b}$ ) currently under an occurrence probability view point from the maximum tolerance levels on local relevant species in these ecosystems or also called Environmental Risk Evaluation (ERA).

Insecta from Diptera order, specifically larval Chironomidae stages are used frequently for bioassays (Rosa et al., 2014) for determine its response (LC50) under different elements present in the environment or in some case where it is necessary know the ecotoxicological response under determined substances. The characteristics of this biological material (in example Chironomus petiolatus, $\mathrm{Ch}$. calligraphus) used for test water or sediments (USEPA, 1994) have short time life cycles, easy management, and low culture requirements under laboratory conditions (Iannacone et al., 2002, 2005; Larraín et al., 1997; Ingersoll et al., 1990; Diepens, 2015; Gagliardi et al., 2016). Also, the larval sensitivity in according to its life stage determine an important variability factor in the results, that shows in reduce the plankton period (life stage I) of these insects (Iannacone et al., 2003). The studies trends to know the reproductive biology, life cycles and culture conditions for its intensive management of species used in ERA, that are important for define the standards conditions of the species that are proposed for be used in toxicity bioassays (Encina et al., 2017a, b).

In this scenario, it would be necessary use of native species, that would support the use of this technique in natural aquatic ecosystems considering the adaptation levels of these species, substituting the use of standardized species that have an evolutive and adaptative origin from other environmental conditions such was observed for microcrustaceans (Daphnia pulex) or microalgae (Selenastrum), in this scenario, the uncertainty would decrease under the moment for stablish the critical levels for establish the secondary character normative (Encina et al., 2017a, b).
In Chilean inland waters there are widespread chironomid species that are reported in rivers with different kind of pollution due human activities (Figueroa et al., 2003, 2007, 2010). One of these species is Paratanytarsus grimmii (Schneider, 1885) that is widespread in natural ecosystems in southern Chile. This species was described with details by Langton et al. (1998), and it has wide distribution and abundant populations (Alexander et al., 1997). The aim of the present study was determine the life cycle, artificial feeding and the laboratory variables for massive culture of native $P$. grimmii as potential biological material for toxicity bioassays.

\section{Material and Methods}

Specimens capture: specimens were obtained from Codihue river ( $\left.38^{\circ} 45^{\prime} 00^{\prime} \mathrm{S}-72^{\circ} 07^{\prime} 59^{\prime \prime} \mathrm{W}\right)$, at $70 \mathrm{~km}$ at east from Temuco, Araucania region, that is an affluent of Colico lake, this river is a pre Andean river that has different kind of rocky substrate (sand, grave, shingles and blocks), being shingles and blocks dominants with hepatics and filamentous algae covering their surfaces. Their river as have native forest and shrubs continous with species such as Fuchsia magellanica, Gunnera tinctoria, Chusque quila, Nothofagus dombeyi and Gevuina avellana with low presence of exotic species. The main anthropic activity in the sub-basin is mainly cattle raising at small scale, and in high zones there are Pinus radiata exotic culture zones. It was collected water parameters as reference at collection moment: temperature $\left(16.8^{\circ} \mathrm{C}\right)$, conductivity $(23.4 \mathrm{mS} / \mathrm{cm})$, total dissolved solids (11.9 mg/L) and $\mathrm{pH}$ (7.10).

Specimens collect and selection: in December 2009, in Codihue river, it done a Paratanytarsus grimmii (Schneider, 1885), larvae collect, in different zones in the shallow zone of the river $(10-40 \mathrm{~cm})$. Different size stones were washed with brushes on plastics bails. Using plastic droplets were separated larvae and deposited in $1 \mathrm{~L}$ plastic bails that were covered with a net of $2 \mathrm{~mm}$ mesh and provided with aeration previous their moving to the laboratory. P. grimmii (Figure 1) is a wide distribution (Murray et al., 2004) and it is parthenogenetic (Langton et al., 1998).
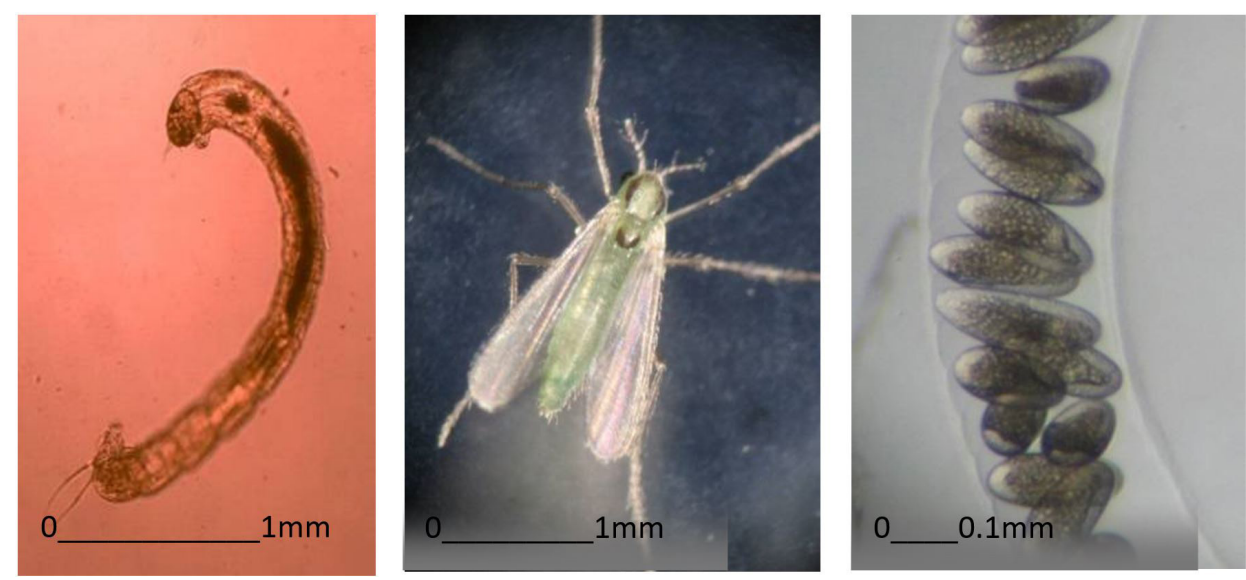

Figure 1. Paratanytarsus grimmii (Schneider, 1885) native species for culture (larvae, female and eggs). 
Culture room and materials: it conditioned a $12 \mathrm{~m}^{2}$ room with controlled temperature $\left(21.6 \pm 1.5^{\circ} \mathrm{C}\right.$ Max and $18.6 \pm 1.8^{\circ} \mathrm{C} \mathrm{Min}$ ), and photoperiod of $14 \mathrm{hr}$ day (06:00 AM- 08:00 PM) and 10 hour darkness (08:00 PM - 06:00 AM). It installed $25 \times 36 \times 30 \mathrm{~cm}$ culture boxes with inside, a $19 \times 12 \times 7 \mathrm{~cm}$ plastic recipient filled with $200 \mathrm{~mL}$ of reconstituted water (INN, 1999), with $16.5 \pm 0.8^{\circ} \mathrm{C}$ as average temperature, and $6.9 \pm 0.5$ as $\mathrm{pH}$ $(\mathrm{n}=9)$. In each recipient was installed an aeration system consistent of electric pump, connected with tubes and aeration stones, it deposited a $4.5 \mathrm{~cm}$ Petri dish filled with water as site of oviposture reception.

Water supplement: in all steps, the water was reconstituted in according to descriptions of Encina et al. (2017a, b) at environment temperature, and the eggs and larvae observations were done using a stereoscopic microscope model Zeiss 4X and optical microscope Olympus.

Feeding: for each culture recipient was supplied substrate and feeding each three days, for this purpose it was utilized $6 \mathrm{~mL}$ of solution with $2 \mathrm{~g}$ mixture and $10 \mathrm{~mL}$ water, the mixture was compound by Urtica sp leaves, commercial ornamental fish food (Tetramin), and sediment consistent of detritus collected in the same river where was obtained the larvae, the proportion of the used mix was of $0.1 ; 1.0: 10$ gr respectively. For sediment getting in the river to the detritus was deleted the water first using single filtration for drying at $110{ }^{\circ} \mathrm{C}$ during 24 hours on stove model Binder series FD. Urtica leaves were dried at $40{ }^{\circ} \mathrm{C}$ during 24 hours, once drying the sediments, leaves and fish food were macerated for obtain a powder previous its use.

Larvae rearing: it determined the $P$. grimmii larvae growth in longitude ( $\mathrm{mm}$ ), measuring daily the total length (from anterior head extreme from the last abdominal segment posterior extreme), to five specimens collected randomly from a cohort exposed to 24 hours thermal shock after hatching, until obtain pupa stage. The measurements were done using the longitude function of the software from a Konuz camera installed on ocular lent of microscope Olympus.

Pupa rearing: the larvae obtained in rearing boxes reach its pupa stage in the same recipient in two days larvae get its metamorphosis in the cocoon that leave swimming to the surface with abdomen movements.

Adults rearing: once finalized the metamorphosis the adult begin the flying localizing in the walls of rearing box. The adult specimen before the third day, fly on the culture boxing and Petri dish. The adult using the surface tension, curve its abdomen sinking it in the water for release the eggs using constant contractions. Pupas and adults individuals were not feed.

Eggs: ovipositions are characterized by a white long gelatinous filament, with ovoids eggs that are adhered to the surface of Petri dishes or hanged in the water column, where are removed with droplets.

\subsection{Larvae and survival bioassays}

Hatching larvae synchornization: for this purpose it stopped the egg development using a water $5^{\circ} \mathrm{C}$ temperature drecreasing, for this objective, it used ovipositions obtained in Petri dishes installed within the rearing boxes daily in five day cycles. For thermal shocks, it used a $5 \mathrm{~L}$ refrigerator Whirpoool model WRD34BDWC, where has inside the ovipositions in $5 \mathrm{~cm}$ diameter Petri dishes, and $100 \mathrm{~mL}$ glass recipient with water for sustain wet and thermometers for obtain a daily temperature record. After fifth day, the ovipositions were retired from refrigerator and deposited at environment temperature in incubation room $\left( \pm 20^{\circ} \mathrm{C}\right)$ obtaining the respective hatching at third day.

Survival assay: with the aim of know the P. grimmii larvae survival response to the manipulation for future bioassays, it done a survival test with 15 replicated for five days, and survival was controlled at 24, 48, 72, 96 and 120 hours. The bioassay was done under $100 \mathrm{~mL}$ of reconstituted water as basis medium in glass recipient, larvae from 2-3 mm length (stage II), 25 individuals for each glass recipient, at $22^{\circ} \mathrm{C}, 14: 10$ hours (light: dark), without feeding and without aeration. It considered dead specimens the specimens with movement absence after touching with a needle of missing after cannibalism. The survival comparisons between the different times were compared using a one-way ANOVA and Tukey multiple comparison test, where the survival percentages were transformed to function arc-sin square root for obtain normality and homocedasticity as previous condition to ANOVA (Zar, 1999), using the software Xlstat.

\section{Results}

Larval growth: during 23 days it was recorded the larval length, the maximum growth was obtained at $20^{\text {th }}$ day $(5.11 \pm 0.40 \mathrm{~mm})$, the days 22 th and 23th it observed pupa stage. The growth rate in length was its best adjust with an exponential curve $\left(\mathrm{R}^{2}=0.931 ; \mathrm{P}<0.05\right)$, with an equation of $\mathrm{y}=0.5912 \mathrm{e}^{0,106 \mathrm{x}}$. During the rearing period it can distinguish a fast growth phase between days 1 to 8 (stage I), with $0.96 \pm 0.30 \mathrm{~mm}$ as average longitude, characterized by individuals that swim free post hatching during the first 48 hours, and the formation of aggregations in the bottom of the recipient covered by sediment $\mathrm{s}$ between third and ninth day. A second phase (stage II) from the days 9 to 14 was characterized by individual shelters with $2.05 \pm 0.51 \mathrm{~mm}$ longitude. The third phase (stage III) from the days 15 to 20 has $4.48 \pm 0.56 \mathrm{~mm}$ longitude, and with cannibalism. A fourth phase (stage IV) from days 21 to 23 characterized by growth stopping at $4.86 \pm 0.22 \mathrm{~mm}$ and pupa stage transformation (Table 1). Each group showed significant differences for Tukey test $(\mathrm{P}<0.01)$.

Survival test: survival bioassays test with stage II larvae showed $100 \%$ survival at 48 hours and $93.3 \%$ at 120 hours (Table 2). The obtained results do not show daily significant differences between different times of the assay $(\mathrm{P}<0.001)$. These results allow denote that $P$. grimmii individuals in stage II have high survival under standard conditions and it can be used as good biological 
Table 1. Average length and growth rate in P. grimmi life stages under laboratory conditions.

\begin{tabular}{cccccccc}
\hline Stage & $\begin{array}{c}\text { Period } \\
\text { (days) }\end{array}$ & Number & $\begin{array}{c}\text { Average } \\
\text { length } \\
\text { (mm) }\end{array}$ & $\begin{array}{c}\text { Variation } \\
\text { coefficient }\end{array}$ & Minimum & Maximum & $\begin{array}{c}\text { Growth } \\
\text { rate } \\
\text { (mm/day) }\end{array}$ \\
\hline I & 1 to 8 & 40 & $0.96 \pm 0.30$ & 0.31 & 0.54 & 1.52 & 0.09 \\
II & 9 to 14 & 30 & $2.05 \pm 0.51$ & 0.25 & 1.34 & 3.07 & 0.18 \\
III & 15 to 20 & 30 & $4.48 \pm 0.56$ & 0.12 & 3.42 & 5.58 & 0.12 \\
IV & 21 to 23 & 15 & $4.86 \pm 0.22$ & 0.04 & 4.59 & 5.34 & 0.0302 \\
\hline
\end{tabular}

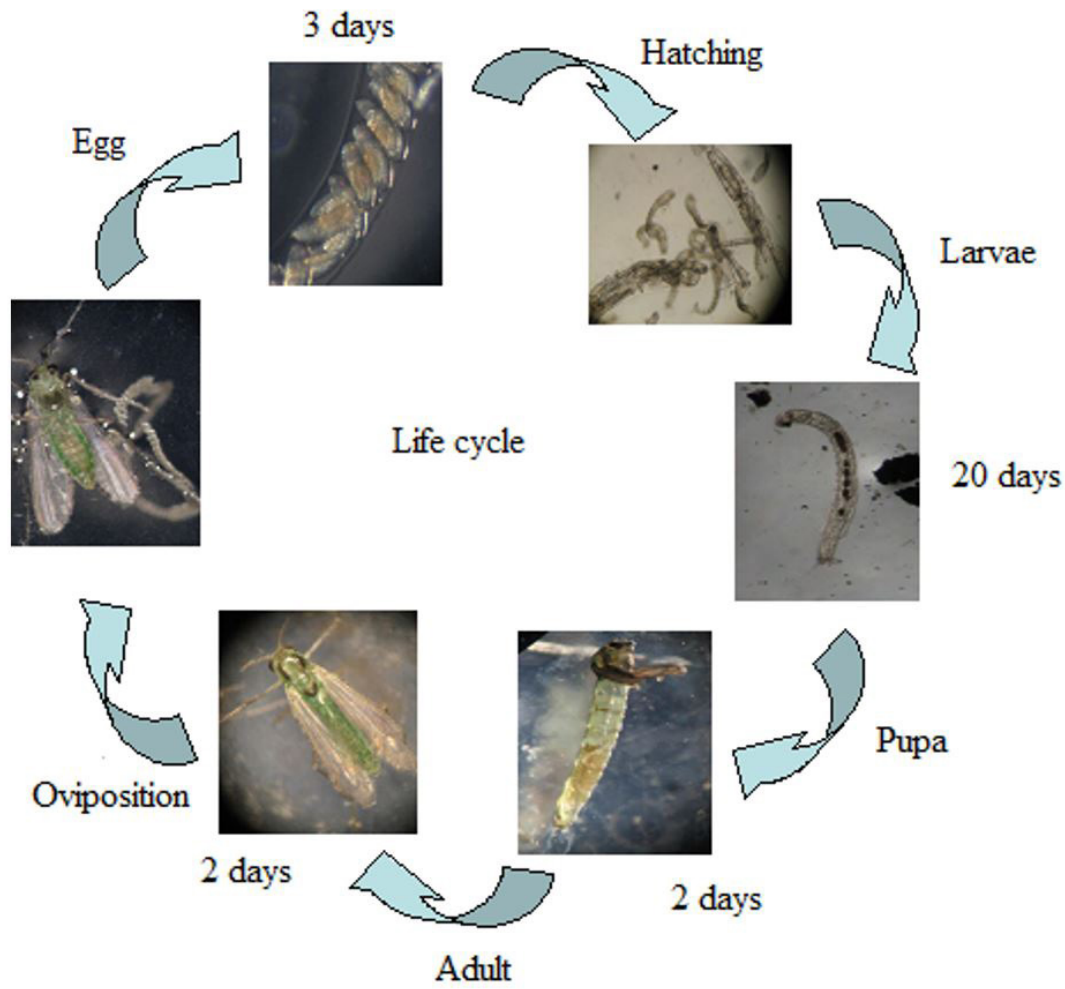

Figure 2. P. grimmii life cycle obtained under controlled conditions.

Table 2. Results of survival test done with stage II larvae obtained under controlled conditions.

\begin{tabular}{ccc}
\hline Time (hrs) & Survival (\%) & $\begin{array}{c}\text { Standard } \\
\text { desviation (\%) }\end{array}$ \\
\hline 24 & 100.0 & 0.0 \\
48 & 100.0 & 0.0 \\
72 & 97.3 & 3.7 \\
96 & 96.0 & 6.0 \\
120 & 93.3 & 11.5 \\
\hline
\end{tabular}

material for ecotoxicological assays (bioassays) because they are easy for manipulate, reduced length variability, low cannibalism mortality probability and metamorphosis at pupa stage.

Eggs and adults manipulation: in 23th day, the adults began to hatch and after a brief time, the individuals begin its flying locating at sides and in the ceiling of rearing boxes. The adult life time late lower than 48 hours, period where parthenogenetic females of 1.5-2.0 mm length deposits their ovipositions as 4.0-4.5 $\mathrm{mm}$ filamentous shape adhered to walls of Petri dishes. The eggs have ovoid shape, adhered at sides each one and immersed in gelatinous mass that has approximately 130 eggs each one.

Life cycle: the used protocol for obtain adults under controlled conditions, allow establish the life cycle of $P$. grimmii under laboratory conditions, that late complete in 27 day, where the larval period late 20 days, pupa two days, adult two days, and eggs three days (Figure 2).

\section{Discussion}

The exposed results agree with literature about Chironomidae use in ecotoxicological bioassays, the literature about standardized species such as Chironomus ripiarus that consisted in reared larvae and do five days experiments (Tassou and Schulz, 2013), similar results were obtained for Chironomus sancticarli (Rebechi-Baggio et al., 
2016). Nevertheless, for Chironomus dilutus it was carried out experiments of 45 days for determine acute toxicity (Du et al., 2014).

Figueiraujo et al. (2018) proposed use of chironomids for environmental pollution evaluation in urban rivers of Brazil, nevertheless they did not specify the specimens at species level, but they cultured specimens and do short time bioassays. This is important considering the importance of Chironomids for local environmental impact studies (Cortelezzi et al., 2013; Serra et al., 2017). In this scenario, in South America there are many water bodies affected by different kinds of human activities that need ecological impacts studies, mainly with native species, first characterizing it for each site (Cortelezzi et al., 2013), as previous step for culture and use in short term experiments (Rosa et al., 2014).

In this scenario, if it is considered that many central Chilean rivers are exposed to pollution to different kinds of human activities (Figueroa et al., 2003, 2007, 2010, 2013). If these ecosystems have many endemic species (Encina et al., 2017c; Vega et al., 2017), it would be necessary first do a specific characterization at species level of species of each site, as previous step for culture (Encina et al., 2017a, b) and bioassays studied compared with standardized species, and finally stablish local ecotoxicological protocols involving native species (Encina et al., 2017a, b).

It can conclude that $P$. grimmii culture is viable in controlled conditions and allow the characteristics for requested requirements for biological material for use in toxicity bioassays first, and second in advance in the native species use in this technique, being a contribution in future process of standards establishment of secondary protection regulations (Environmental Secondary Quality Norm).

\section{Acknowledgements}

The present study was funded by the project MECESUP $\mathrm{UCT}^{\circ} \mathrm{N}^{\circ} 0804$. We also express our gratitude to M. I. and S.M.A for thier valuable comments that improved the manuscript.

\section{References}

ALEXANDER, M., MERRITT, R. and BERG, M., 1997. New strategies for the control of the parthenogenetic chironomid (Paratanytarsus grimmii) (Diptera: Chironomidae) infecting water systems. Journal of the American Mosquito Association, vol. 13, no. 2, pp. 189-192. PMid:9249659.

CORTELEZZI, A., SIERRA, M.V., GÓMEZ, N., MARINELLI, C. and RODRIGUES CAPÍTULO, A., 2013. Macrophytes, epipelic biofilm, and invertebrates as biotic indicators of physical habitat degradation of lowland streams (Argentina). Environmental Monitoring and Assessment, vol. 185, no. 7, pp. 5801-5815. http://dx.doi.org/10.1007/s10661-012-2985-2. PMid:23149840.

DE LOS RIOS ESCALANTE, P., MERUANE, J., MORALES, M.C., RUDOLPH, E., FUENTEALBA, C. and BOXSHAL, G., 2013. Zoogeography of Chilean inland water crustaceans. Latin American Journal of Aquatic Research, vol. 41, no. 5, pp. 846-853. http://dx.doi.org/10.3856/vol41-issue5-fulltext-5.
DIEPENS, N.J., 2015. Sediment toxicity testing and prospective risk assessment of organic chemicals. Wageningen: Wageningen University. PhD Thesis.

DU, J., LI, Y., HUANG, C. and YOU, J., 2014. Chronic toxicity threshold for sediment-associated benzo[a]pyrene in the midge (Chiromonus dilutes). Archives of Environmental Contamination and Toxicology, vol. 66, no. 3, pp. 370-378. http://dx.doi.org/10.1007/ s00244-014-0005-y. PMid:24553811.

ENCINA, F., DE LOS RÍOS-ESCALANTE, P. and SALAZAR, K., 2017a. Acute toxicity $\left(\mathrm{LC}_{50}\right)$ of a pesticide (Carbendazim) on two native crustacean zooplankton species Daphnia pulex Leydig, 1860 and Tumeodiaptomus diabolicus (Brehm, 1935) from Northern Patagonian lakes (Chile). Crustaceana, vol. 90, no. 2, pp. 199-206. http://dx.doi.org/10.1163/15685403-00003637.

ENCINA, F., DE LOS RÍOS ESCALANTE, P. and SALAZAR, K., 2017b. Culture of native species of zooplanktonic crustaceans Tumeodiaptomus diabilicus (Brehm, 1935) from northern Patagonian lakes (Chile). Crustaceana, vol. 90, no. 13, pp. 1599-1603. http:// dx.doi.org/10.1163/15685403-00003713.

ENCINA, F., VEGA, R., LARA, G. and DE LOS RÍOSESCALANTE, P., 2017c. Ecological role of benthic crustaceans in Chilean North Patagonian lakes and rivers (Araucania region, $39^{\circ}$ S). Crustaceana, vol. 90, no. 4, pp. 437-447. http://dx.doi. org/10.1163/15685403-00003643.

FIGUEIRAUJO, R.B., RODRIGUES, L.F.T., FALCI, L., AMARAL, P.H.M., SILVA, M.V.D. and GAMA, R., 2018. Potential effectiveness of reducing taxonomic and numerical resolution when using macroinvertebrates to characterize impacted streams in southeastern Brazil. Fundamental and Applied Limnology, vol. 191, no. 2, pp. 87-97.

FIGUEROA, R., BONADA, N., GUEVARA, M., PEDREROS, P., CORREA-ARANEDA, F., DÍAZ, M.E. and RUIZ, V.H., 2013. Freshwater biodiversity and conservation in mediterranean climate streams of Chile. Hydrobiologia, vol. 719, no. 1, pp. 269289. http://dx.doi.org/10.1007/s10750-013-1685-4.

FIGUEROA, R., PALMA, A., RUIZ, V. and NIELL, X., 2007. Análisis comparativo de índices bióticos utilizados en la evaluación de la calidad de aguas en un río mediterráneo de Chile, río Chillán, VIII región. Revista Chilena de Historia Natural, vol. 80, no. 2, pp. 225-242. http://dx.doi.org/10.4067/S0716-078X2007000200008.

FIGUEROA, R., RUIZ, V.H., BERRÍOS, P., PALMA, A., VILLEGAS, P. and ANDREU-SOLER, A., 2010. Trophic ecology of native and introduced fish species from Chillan river, south-central Chile. Journal of Applied Ichthyology, vol. 26, no. 1, pp. 78-83. http://dx.doi.org/10.1111/j.1439-0426.2009.01347.x.

FIGUEROA, R., VALDOVINOS, C., ARAYA, E. and PARRA, O., 2003. Macroinvertebrados bentónicos como indicadores de calidad de agua de ríos del sur de Chile. Revista Chilena de Historia Natural, vol. 76, no. 2, pp. 275-285. http://dx.doi.org/10.4067/ S0716-078X2003000200012.

GAGLIARDI, B.S., PETTIGROVE, V.J., LONG, S.M. and HOFFMANN, A.A., 2016. A meta-analysis evaluating the relationship between aquatic contaminants and chironomid larval deformities in laboratory studies. Environmental Science \& Technology, vol. 50, no. 23, pp. 12903-12911. http://dx.doi. org/10.1021/acs.est.6b04020. PMid:27787987.

IANNACONE, J., ALVARIÑO, L. and MANSILLA, J., 2002. Actividad insecticida de cuatro extractos botánicos sobre larvas de los mosquitos Culex quinquefasciatus (Diptera: Culicidae) 
y Chironomus calligraphus (Diptera: Chironomidae). Wiñay Yachay, vol. 6, pp. 56-71

IANNACONE, J., ARRASCUE, A. and CÁRDENAS, M., 2005. Assessment of ecotoxicity of sediments of Aruri River and Junin Lake (Perú) employing Escherichia coli and Chironomus calligraphus. Brazilian Journal of Toxicology, vol. 18, no. 1, pp. 27-41.

IANNACONE, J., SALAZAR, N. and ALVARIÑO, L., 2003. Variabilidad del ensayo ecotoxicolgico con Chironomus calligraphus Goeldi (Diptera: Chironomidae) para evaluar cadmio, mercurio y plomo. Ecología Aplicada, vol. 2, no. 1, pp. 103-110.

INGERSOLL, C.G., DWYER, F. and MAY, T., 1990. Toxicity of organic and inorganic selenium to Daphnia magna (Cladocera) and Chironomus riparius (Diptera). Environmental Toxicology and Chemistry, vol. 9, no. 9, pp. 1171-1181. http://dx.doi.org/10.1002/ etc. 5620090908 .

INSTITUTO NACIONAL DE NORMALIZACIÓN - INN, 1999. Norma Chilena Oficial NCH2083: aguas-bioensayo de toxicidad aguda mediante la determinación de la inhibición de la movilidad de Daphnia magna o Daphnia pulex (Crustacea, Cladocera). 1. ed. Chile: Instituto Nacional de Normalización, pp. 1-19.

LANGTON, P., CRANSTON, P. and ARMITAGE, P., 1998. The parthenogenetic midge of water suplly systems, Paratanytarsus grimmii (Schneider) (Diptera: chironomidae). Bulletin of Entomological Research, vol. 78, no. 2, pp. 317-328. http:// dx.doi.org/10.1017/S0007485300013080.

LARRAIN, A., RIVEROS, A., BAY-SCHMITH, E. and ROA, R., 1997. Evaluation of three larval instars of the midge Chironomus petiolatus as bioassay tools using a computationally intensive statistical algorithm. Archives of Environmental Contamination and Toxicology, vol. 33, no. 4, pp. 407-414. http://dx.doi.org/10.1007/ s002449900270. PMid:9419259.

MURRAY, D., HUGHES, S., FURSE, M. and MURRAY, W., 2004. New records of Chironomidae (Diptera: Insecta) from the
Azores, Macaronesia. International Journal of Limnology, vol. 40, no. 1, pp. 33-42. http://dx.doi.org/10.1051/limn/2004004.

REBECHI-BAGGIO, D., RICHARDI, V.S., VICENTINI, M., GUILOSKI, I.C., ASSIS, H.C.S. and NAVARRO-SILVA, M.A., 2016. Factors that alter the biochemical biomarkers of environmental contamination in Chironomus sancticaroli (Diptera, Chironomidae). Revista Brasileira de Entomologia, vol. 60, no. 4, pp. 341-346. http://dx.doi.org/10.1016/j.rbe.2016.07.002.

ROSA, B.J., RODRIGUES, L.F., OLIVEIRA, G.S. and GAMA ALVES, R., 2014. Chironomidae and oligochaeta for water quality evaluation in an urban river in southeastern Brazil. Environmental Monitoring and Assessment, vol. 186, no. 11, pp. 7771-7779. http://dx.doi.org/10.1007/s10661-014-3965-5. PMid:25130902.

SERRA, S.R.Q., GRACA, M.A.S., DOLEDEC, S. and FEIO, M.J., 2017. Chironomidae traits and life history strategies as indicators of anthropogenic disturbance. Environmental Monitoring and Assessment, vol. 189, no. 7, pp. 326. http://dx.doi.org/10.1007/ s10661-017-6027-y. PMid:28600682.

TASSOU, K.T. and SCHULZ, R., 2013. Low field-relevant tubufenozide concentrations affect reproduction in Chironomus ripiarus (Diptera: Chironomidae) in a long-term toxicity test. Environmental Science and Pollution Research International, vol. 20, no. 6, pp. 3735-3742. http://dx.doi.org/10.1007/s11356012-1311-4. PMid:23161502.

US ENVIRONMENTAL PROTECTION AGENCY - USEPA, 1994. EPA/600/R-94/029: methods for measuring the toxicity and bioaccumulation of sediment-associated contaminants with freshwater invertebrates. Duluth: Office of Research and Development, US Environmental Protection Agency, pp. 133.

VEGA, R., DE LOS RÍOS-ESCALANTE, P., ENCINA, F. and MARDONES, A., 2017. Ecology of benthic crustaceans in Cautin river ( $39^{\circ} \mathrm{S}$, Araucania region, Chile). Crustaceana, vol. 90, no. 6, pp. 709-719. http://dx.doi.org/10.1163/15685403-00003689.

ZAR, J., 1999. Biostatistical analysis. New Jersey: Prentice Hall, $661 \mathrm{p}$. 